\title{
A British Perspective
}

Grace Davie

\section{(2) OpenEdition}

Journals

Electronic version

URL: http://journals.openedition.org/assr/24569

DOI: 10.4000/assr.24569

ISSN: $1777-5825$

\section{Publisher}

Éditions de l'EHESS

\section{Printed version}

Date of publication: 30 December 2012

Number of pages: 91-100

ISSN: 0335-5985

\section{Electronic reference}

Grace Davie, «A British Perspective », Archives de sciences sociales des religions [Online], 160 l octobredécembre 2012, Online since 20 February 2016, connection on 03 May 2019. URL : http:// journals.openedition.org/assr/24569; DOI : 10.4000/assr.24569 


\section{Grace Davie}

\section{A British Perspective}

I have very much enjoyed reading this book - for two reasons. The first is straightforward: the book tells me a great deal about the present state of Catholicism, both in France and elsewhere. The editors have done a fine job in producing a well-written, well-organized and wide-ranging volume full of valuable information. This is a text to put into the hands of many different people. The second reason has more to do with indirect rather than direct gain: I see in these pages a mirror of my own experience and find myself asking new questions as a result. Some of the issues raised in these chapters can be transposed to the British situation relatively easily; others cannot, given the different kinds of church life that dominate on this side of the Channel. But either way, the underlying question remains the same: how do the historically dominant churches of (mostly) Europe come to terms with the changing nature of late modern societies?

"Historically dominant" is the key phrase here. The first four chapters of this volume describe the current situation of the Catholic Church in France, Spain, Italy and French-speaking Canada. Each story is distinctive but we see in all of them an institution that can no longer control the beliefs and the behaviour of the population in question, but has not - therefore - ceased to exist. The fact that the reference in Québec is regional, rather than national, makes no difference to the argument. Despite huge and irreversible changes, all four churches remain significant players in the society in question and can still attract the passive allegiance of large sections of the population. Exactly the same is true of the equivalent institutions in the different parts of the United Kingdom, though their histories are very different.

The most important common element lies in the fact that these churches are territorially - based, whether at a national, regional or local level. It is for this reason that the parish becomes a key aspect of the analysis. Specifically, what happens to the notion of parish when the institution in question can no longer afford to maintain a "universal" system, in the sense that there is an ordained priest in every corner of the land who has responsibility for the people who live there whether they recognize this or not. European churches are at different points on a continuum in this respect. Those that are better funded and have correspondingly large numbers of employees (including priests) have barely engaged the question. Italy would be the obvious example here. Others have long since abandoned the notion of universality given the dramatic drop in vocations, but have discovered ingenious ways to maintain "presence" - through the diaconate and through lay ministries of many kinds. What this book makes so clear is that these innovative strategies provoke new questions, both for the churches themselves and for those who study them. Some of these have to do with the 
meaning of ordained ministry: in what way is this distinctive? Others have to do with gender: who can or cannot do what? These questions are addressed in a number of the chapters gathered here, both in Part II (concerning public roles) and Part III (in relation to gender).

Capturing the present situation regarding religion in Europe isn't easy for the simple reason that many different things are happening at once. In my own writing, I have identified six factors that must be taken into account (Davie, G., 2006, "Religion in Europe in the $21^{\text {st }}$ century: The factors to take into account", Archives européennes de sociologie/European Journal of Sociology/Europaeisches Archiv für Soziologie, XLVII/2, 2006: 271-96).

The crucial point to remember is that these factors push and pull in different directions, meaning that it is very unlikely that we will find a single narrative that covers everything. The six factors are: (a) the role of the historic churches in shaping European culture; (b) an awareness that these churches still have a place at particular moments in the lives of modern Europeans, though they are no longer able to discipline the beliefs and behaviour of the great majority of the population; (c) an observable change in the church-going constituencies of the continent, which operate increasingly on a model of choice, rather than a model of obligation or duty; (d) the arrival into Europe of groups of people from many different parts of the world, and with very different religious aspirations from those seen in the host societies; (e) the reactions of Europe's secular elites to the increasing salience of religion in public as well as private life; and (f) a growing realization that the patterns of religious life in modern Europe should be considered an "exceptional case" in global terms - they are not a global prototype.

Not all of these are equally important for the present discussion, though the first three resonate repeatedly in the chapters that I have been reading. This book describes very clearly the shifting nature of the Catholic churches under review as they mutate from a situation of dominance (one could almost say hegemony) to one in which they are simply one organization amongst many others (both religious and secular) which compete for the attentions of different kinds of people. It is quite clear, moreover, that some forms of Catholicism are rather more successful than others - there is a market within Catholicism, quite apart from competition from outside. A side-effect of this, which this book explores in some detail, is the tension between adaptation and regulation within the institution itself, remembering that the conservative options (those associated with authority) are themselves simply one choice among many. Paradoxically they are often relatively popular - clearly there is a market for "certainty".

The fourth and fifth factors listed above are relevant in a different way in that they account for an increasingly evident paradox. It is clear that two rather different things are happening at once in the religious life of Europe. On the one hand are the increasing levels of secularity, which lead in turn to a manifest 
decline in practice and belief (at least in their more orthodox forms) and - more importantly for this discussion - in levels of religious literacy. On the other is a series of increasingly urgent debates about religion in the public square. Many of these debates concern the nature of a religiously plural society - specifically the rights of religious minorities to sustain forms of behaviour or dress, which challenge the norms of the host society. Others, however, are closer to the material included in this book in that they reflect the moral and political dilemmas provoked by the advances in medicine and science. What, without exaggeration, was unthinkable one or two generations ago, is now common place: for example, a child can be conceived outside the womb and same sex couples can become parents. Similar issues surround the prolongation of life by artificial means. Who, for instance, is able to turn off a life-support machine and on what authority? In short the sensitivities surrounding the beginning and end of life have become increasingly prominent - unsurprisingly in that they raise in turn the meaning of life itself.

This largely unexpected combination - i.e. of declining religious literacy alongside a renewed attention to religious and moral issues - is difficult to manage. The reason for this is clear: European populations are losing their knowledge of religion (of vocabulary, concept and narrative) just when they need these most - given the requirement, on an increasingly regular basis, to pass judgement on the rights and obligations of the very varied religious actors now present in Europe, and on the delicate and very personal issues that have become topics of public discussion. Should we be surprised, therefore, that the consequent debates are often both ill-informed and ill-mannered? That said, and despite continuing secularization, many Europeans continue to assume that the churches, including the Catholic Church, will still have something to say with respect to bio-ethical debates, but they can no longer dominate the discussion. Precisely these issues are raised in Part III of this book. I have read these contributions with great interest.

The final part of the book has a cultural resonance. It also contains a chapter that I find particularly appealing. It is the account of René Rémond's unique contribution to Catholic thinking, more specifically of the genesis, publication and reception of Le christianisme en accusation, a book that appeared in 2000 . I was fascinated by this discussion for several reasons. First because as a young doctoral student working on the political leanings of French Protestants in the interwar period (including those on the right), I was instructed to read, among other things, Les Droites en France. I did this with immense benefit. Second, I am drawn to reflect on the notion of a Catholic intellectual, remembering that France is a society in which the concept of "public intellectual", whether Catholic or not, is unremarkable; this is much less the case in Anglo-Saxon countries. For this reason, I cannot imagine an equivalent chapter in a book published in Britain. Third I was fascinated not only by the story that lay behind this particular publication (how it came about), but even more so by its gradual emergence as 
a best-seller and what this tells us about the various constituencies that bought it. The markedly ambiguous picture that emerges is in a way quintessentially French; the underlying questions, however, penetrate more widely.

With this in mind, I am tempted to speculate on the contents page of a British equivalent to Catholicisme en tensions, remembering that even the idea is difficult in a country which contains four distinct religious cultures, rather than one: England, Scotland, Wales and Northern Ireland have very different religious cultures. I hope that my compatriots will forgive me if I concentrate on the first of these and if I confine my remarks to the Church of England - acknowledging that this is a very partial account.

Much would be very similar to the Catholic case at least in its European forms, crucially the struggle to maintain any kind of comprehensive cover (in a territorial sense) when the resources no longer permit. Here the English situation is comparable to the French case - though the strains are felt in different ways. And just as French Catholics might look enviously at their relatively well-funded Italian cousins, so also do members of the impoverished Church of England compare themselves with the Nordic Lutherans whose budgets remain substantial. Anglicans, however, are pragmatic - they have evolved multiple and piecemeal solutions to their problems. Lay-ministries of all kinds have evolved, notably the role of (lay) reader, through which the institution maintains both "presence" and liturgy. "The office of Reader is the only lay ministry in the Church of England which is voluntary, nationally accredited, Episcopally licensed and governed by canon. There are now over 10,000 Readers, with men and women represented almost equally." (See http://www.readers.cofe.anglican.org/info.php for more information - accessed 19 October 2012). Both the similarities and the differences with the Catholic case become clear very quickly. Both institutions improvise, but "readers" are not "deacons" (in the Catholic sense) and the question of gender is simply not an issue. The latter is hardly surprising given that the Church of England has been ordaining women as priests for some twenty years.

That said, the possibility that women might become bishops remains highly controversial given that bishops have oversight over a whole diocese, including those parishes which up to now have "opted out" - a typically English solution which effectively allows exceptions to the rule. The details of "opting out" are complicated, but the essential point is simple enough: those parishes that do not accept the ordination of women can place themselves under the oversight of an alternative bishop (known formally as a "provincial episcopal visitor") who has never ordained a woman. In other words they step outside the diocesan system. Whether or not this arrangement should continue has provoked heated debate. What was appropriate as a short term solution, put in place to manage change (the initial phase of the ordination of women), is less acceptable in the longer term - especially to those women whose (potential) episcopal ministry is cast in doubt as a result. Will she or will she not be the bishop of the whole diocese? 
Quite apart from the position of women, the role of bishop is interesting in itself, and that of archbishop even more so. Why does this position still attract public attention in a society which is so evidently secular? At the time of writing there is intense speculation about the appointment of the next (the $105^{\text {th }}$ ) Archbishop of Canterbury. This is not the place to describe the process by which this occurs (suffice it to say that it is very different from a Catholic appointment); it is perhaps the place to note that when the name is finally announced it will undoubtedly be headline news and comments will come from every sector of society - indeed from all over the world. The reason for the latter is the fact that the Archbishop of Canterbury is not only the Primate of All England but is the head of the Anglican Communion (some 80 million Anglicans worldwide). It follows that any volume entitled Anglicanisme en tension would have to take this into account. Specifically, an awareness that the vast proportion of active Anglicans now live in the global south, and have markedly more conservative views than their northern counterparts on a whole range of issues - notably the question of homosexuality - is a major source of tension at every level of the Communion. These differences are acutely felt and remain largely unresolved.

A second topic that would almost certainly figure in an English volume would be the continuing debate about (a) religious education in schools and (b) the place of the churches (both Catholic and Anglican) in the national school system. Clearly the two are related but raise rather different issues. The first however picks up a point already made: that is an increasing awareness that levels of religious literacy are not only declining fast in modern Britain but are no longer adequate for the task in hand - this being the careful and just management of a religiously plural society. So what is to be done? One place to start is in the school system, where religious education remains a compulsory element in the curriculum. Students of all ages need to be better informed about religions of all kinds, including those historically present in their own country. This is largely agreed in principle, but the situation "on the ground" is patchy to say the least. The teaching of religion in schools can be excellent, but all too often, it is under-resourced, taught by non-specialists and marginalized in the school as a whole. The corresponding tensions would merit a developed discussion in my imagined text.

An interesting episode draws some of these points together. In February 2008, the present Archbishop of Canterbury, Dr. Rowan Williams, was invited to give the foundation lecture in the Temple Festival series at the Royal Courts of Justice - a series devoted to the place of Islam in English law. (See http:// www.archbishopofcanterbury.org/articles.php/1137/archbishops-lecture-civil-andreligious-law-in-england-a-religious-perspective for more details and for the text of the lecture, accessed 19 April 2012). Given the importance of this occasion and indeed of the topic itself, the lecture was preceded by a live interview with the Archbishop on the main news channel (BBC Radio 4, World at One). (See http://www.archbishopofcanterbury.org/articles.php/707/archbishop-on-radio-4uk-law-needs-to-find-accommodation-with-religious-law-codes, accessed 19 April 
2012). The address itself was a learned exposition to an academic audience in which the Archbishop invited the legal establishment to engage with religious legal codes and - where appropriate - to accommodate religious perspectives, as it had already done with the Jewish Halacha. There is, moreover, a place for theology in these discussions. The preceding interview was necessarily different in style, but covered the same ground, including a specific, though careful, reference to the Islamic system of Sharia. Interestingly it also included more general questions of conscience regarding medical practice and moral issues.

What was said was one thing; what was heard quite another. The response was immediate, vehement and largely negative. One commentator puts this as follows: "It is hard to believe that this scholarly, even esoteric, lecture could ignite the intensely hostile reaction it has - not only in the tabloid press (a familiar accompanying cacophony on every issue it seeks to exploit for commercial purposes) but at all levels of the media". (The commentator, Tina Beattie, is professor of Catholic studies at Roehampton University, England. See http://www.open democracy.net/article/faith_ideas/europe_islam/sharia_law_uk, accessed 19 October 2012). It is clear that the provocation came more from the interview than the lecture as such, but even here there is evidence of deliberate misreading - not to mention a manifest and woeful ignorance concerning the issues under discussion. Any notion of religious literacy is conspicuous by its absence.

But why were the media so attentive to what the Archbishop said? The membership of the Church of England is small and getting smaller, it is frequently seen as a marginal institution in modern society, and its teachings seem not to impinge on the beliefs and behavior of the great majority of English people. So why does it matter what its leader says? That is the paradox that requires an explanation; it is also a situation that generates considerable tension for whoever is the current holder of the post. The Archbishop of Canterbury is expected to speak on the issues of the day, but what must he say? It is quite impossible for him to please everyone. Indeed on this occasion, there were many within, as well as outside, the Anglican Church who took issue with what the Archbishop proposed.

Which brings me to my final point. Is Dr. Williams a public intellectual after all? In one sense, yes - but not I think in the French understanding of the term. Dr. Williams is a deeply learned man, with a background in academia and will become the Master of a Cambridge college on "retirement" from his present responsibilities. He is also a public figure by virtue of the post that he has held for the last ten years. But, I do not see him as a public intellectual in the sense that René Rémond is presented in the volume that prompted this discussion. It is equally hard to imagine an English equivalent to the "Centre catholique des intellectuels français" (which René Rémond directed) - such an institution reflects an entirely different intellectual culture from that which exists in Britain.

Grace DAVIE University of Exeter, UK G.R.C.Davie@exeter.ac.uk 